Gerhard Preyer*

Goethe-University, Frankfurt am Main, Germany

e-mail: preyer@em.uni-frankfurt.de

\title{
On Contemporary Philosophy of Mind From the 1950s Years to the Present
}

DOI: http://dx.doi.org/10.12775/RF.2015.001

\section{Initial Situation in the 1950s Years}

1. Turn to naturalism and materialism. In the philosophy of the 20th century the Cartesian picture of epistemology, and British empiricism tradition (John Locke, George Berkeley, David Hume) was rejected from different philosophical directions. In the community of philosophers is wellknown that there are no private objects, private language, ghost in the machine, Cartesian theatre, and the myth of the given. Philosophers like Ludwig Wittgenstein, Willard van Orman Quine, Wilfrid Sellars, Donald Davidson, Richard Rorty, and not to forget Martin Heidegger, and others have claimed to cut Cartesian epistemology. Epistemologically the turn of the Anti-Cartesians are made from the third-person point of view. The versions of naturalized epistemology, speaking a grosso modo, is the externalist point of view: the subjective point of view is from outside. This was empathized, for example, by Robert C. Stalnaker. ${ }^{1}$

Prof. Dr. phil. Gerhard Preyer, Professor of Sociology, Editor-In-Chief, ProtoSociology, An International Journal of Interdisciplinary Research and Project, GoetheUniversity Frankfurt am Main, D-60054 Frankfurt a. M., www.fb03.uni-frankfurt. de/48480132/gpreyer, www.protosociology.de; Academia: https://uni, frankfurt.academia.edu/GerhardPreyer, Youtube: http://www.youtube.com/user/ProtoSociology

1 R. C. Stalnaker, Our Knowledge of the Internal World, Oxford 2008. From Stalnaker's point of view there is also the curious statement of Davidson "I do not accept Quine's account of the nature of knowledge, which is essentially first person and Cartesian," p. 2. 
Since the mid of 1960s years the naturalized epistemology (naturalism, physicalism/materialism) has taken effect in the American philosophy of mind, and has spread in the European philosophy. There is a convergence between all versions of naturalized epistemology that they deny the Cartesian tradition, empiricism, the phenomenological tradition of Edmund Husserl, Rudolf Carnap's linguistic frameworks, constructivists epistemologies, and Nelson Goodman's Ways of World Making. ${ }^{2}$ This is not self-evident, and needs a particular explanation. The turn against this traditions culminates in Davidson's "third dogma of empiricism", that is, the distinction between "scheme and content".

The successes of biochemistry, neurophysiology, the orientation of logical empiricism to natural sciences, and its critique on Scheinprobleme had initiated this turn. Psychology was dominated by behaviourism. This turn was underpinned by the significance of mathematical logic in the philosophy of the 20th century. A particular relevance has had Wilfrid Sellars' article "Empiricism and the Philosophy of Mind" $(1956)^{3}$. For him mental states are neural states. Since the mid of the 1950s years there was from a naturalistic point of view (again) a turn to the philosophy of mind (Quine, John C. Smart, Ullian T. Place). Naturalism and Materialism was accepted in the 1960s years in the philosophical community extensively. The naturalization of epistemology is a reduction of features of the mental to natural data, which are to describe, and to explain by physics as a basic science. Their entities are to specify to the space-time frame of reference (Quine). Physicalism (materialism) is a stronger account because the entities as physical one are completely explained by physics finally. Saul A. Kripke, Frank Jackson, David Chalmers, and Martina Nida-Rümelin, for example, are in contrary to a monistic account in the philosophy of mind.

2. Unconscious mental states. Many philosophers agree that the role of mental states in explaining behaviour is also relevant also in cases these states are not conscious. Not all mental states are conscious immediately I may have. Since the end of the 19th century the distinction between conscious, and unconscious mental states has been made. John R. Searle, and Fred Dreske, for example, continue this tradition. ${ }^{4}$ For both, most mental states are not conscious. Descartes, Locke, and also Aristotle assumed that this is not the case. In Leibniz' Monadology we find the concept of petite perception. This idea does not take effect in the

2 N. Goodman, Ways of World Making, Indianapolis 1978.

3 In W. Sellars, Science, Perception, and Reality, London 1963, pp. 127-96.

4 Searle argues that unconscious are potential conscious mental states (connection principle). Unconscious mental states are to understand as conscious mental states. I think Searle is right that there is no unconscious rule following or Freudian unconsciousness. 
philosophy of the 18th century. From my point of view we need another answer of the problem of unconscious states as we know, for example, from the psychoanalytic tradition, and in the contemporary philosophical scene, because a unconscious consciousness is a contradiction notion like Jean-Paul Sartre, Franz Brentano, and Edmund Husserl have argued. ${ }^{5}$ It is not disputed that Sigmund Freud's concept of unconsciousness is a problematic one, which we have to give up ultimately. ${ }^{6}$ But I do not dispute that there are motivated mental dispositions as background of conscious states.

\section{Turn since the 1960 s Years}

1. Non-reductive physicalism and functionalism. The critique of the popular type-type-identity theory (Smart) by Hilary Putnam (multi-realization of mental states), and Davidson (anomalous monism) have had as consequence that the most naturalists gave up the type-type-identity theory by the concept of supervenience. ${ }^{7}$ This had initiated the debate on nonreductive physicalism, mental causality, and supervenience. ${ }^{8}$

5 On a the current debates in the philosophy of mind, and the pre-reflective foundation of consciousness, see, Preyer, Miguens, Clara Morando Bravo (eds.), PreReflectivity. Sartre and Contemporary Philosophy, Abingdon: Routledge 2015.

6 On a critique, for example, A. C. Macintyre, The Unconscious. A Conceptual Analysis, London: Routledge 1958.

7 It is to make the distinction between "conditions of identity", "types of objects", and "conditions of confirmation" of a different individuation within a universe of an object type (P. Geach, D. S. Shwayder, D. Henrich).

8 Firstly the concept of supervenience is used in practical philosophy. The account was, for example, that the evaluation of two actions as good or bad, and of two entities as beautiful or ill-favoured is not changed in the case of their complete sameness. It was assumed a supervenience of evaluative over physical properties without a reduction of the first to the second. In the philosophy of mind since the 1970s years the concepts of supervenience are use to express dependence of the mental from the physical. The explanatory power of concepts of supervenience are not to overestimate. Also a strong supervenience is in harmony with different solutions of the mind-body problem, for example, different versions of the identity theory, epiphenomenalism, parallelism, and even with emergentism. The application of the concept of supervenience on the interdependency between physical and mental states goes to Davidson, "Mental Events," (1970), pp. 207-25. In Actions and Events, Oxford 1980. In the meantime there is an extensive literature about the explanatory power of supervenience, and the versions of supervenience are systemized, see, for example, F. von Kutschera, Die falsche Objektivität, Berlin 1993, pp. 23-33, "Supervenience and Reduction," Erkenntnis 36, 1992, pp. 33-43. Philosophie des Geistes, Paderborn 2009, pp. 140-146, 155-170. On mental causation and supervenience, for example, J. Kim, Philosophy of Mind, New York 1996, Kim, Supervenience and Mind. Selected Philosophical Papers, Cambridge 1993, E. E. Savellos (ed.) (1995): Supervenience: New Essays, Cambridge, E. Rogler, G. Preyer, Materialismus, anomaler Monismus und mentale Kau- 
The defence of naturalized epistemology since the 1970s years was an ontological, and also an ideological one. ${ }^{9}$ It is to mention that the problem of mental causation is confused if its description is pictured in two ranges from the mental downward, and body movement upward, which converge in an action. ${ }^{10}$

Putnam's functionalism (analytical and scientific functionalism) is a critique on materialism (Smart) as a prominent position at the end of the 1950s years. "1 "Analytical functionalism" means theoretical terms are defined by the application of theories. The definition of causal functional roles is an analytical (a priori) knowledge thereby we describe mental states. The meaning of commonsense mental concepts are defined by commonsense theories.

Putnam's first functionalism is a characterization of mental states by a mathematical description of a computer program. There are two theories, which have taken effect in the theory of mind:

1. The functional role theories: the functional role semantics is the heart of the functionalism (Sellars, and others). Such theories lead to a meaning nominalism, which is shared among different philosophical traditions, for example, Quine, Davidson, and Paul Grice. This is a unstable position ultimately. Jerry Fodor rejects this semantics because the content of thoughts is not a function of conceptual, or functional roles. For him there are concepts, and mental representations.

2. The causal theory of content: a causal semantics claims to explain why mental symbols, and world are related on the way that the symbols have their extensions and intensions, which they have (Fodor). The answer is that causal relations give us the facts about such relations and contents. It is the intent of the causal theory to integrate the semantic content of the language of thoughts with the naturalization of intentionality (language). This theory claims to give by non-semantic and non-

salität. Zur gegenwärtigen Philosophy des Mentalen bei Donald Davidson und David Lewis, Frankfurt a. M., pp. 25-62, "Anomalous Monism and Mental Causality. On the Debate of Donald Davidson's Philosophy of the Mental." Free to download https://ssl.humanities-online.de see, OpenAcess ${ }_{L}$ T. Burge, "Mind-Body Causation and Explanatory Practice" (1993), (capt. 16), on J. Kim, see also, Burge, "Postscript to "Mind-Body Causation and Explanatory Practice" (2006) (capt. 16). In Foundation of Mind, Oxford 2007.

9 Burge, "Mind-Body Causation and Explanatory Practice", p. 360. In Foundation of Mind.

10 G. H. von Wright, "Die menschliche Freiheit," pp. 136-37. In Normen, Werte und Handlungen, Frankfurt a. M. 1994.

11 On a non-reductive version J. Fodor, RePresentation, Cambridge 1981; on an analytic version D. Armstrong, A Materialist Theory of Mind, New York 1968, D. Lewis, "Psychophysical and Theoretical Identification," Australasian Journal of Philosophy 50 1972, pp. 249-58, S. Shoemaker, "Functionalism and Qualia." In Identity, Cause and Mind, Cambridge 1984. H. Putnam, "The Nature of Mental States". In Philosophical Papers II, Cambridge 1975 had argued for a scientific version. 
intentional concepts sufficient conditions that a part of the world represented another part of the world (representations).

2. Principle problems. The question is in principle: are functionalizable mental properties without lose their meaning? Does represent the concept of qualitative states their causal role? Have phenomenal states causal power?

If functionalism were true then there would be no distinction between inside and outside of the skin. Both would be related causally. Functionalism is a third-person approach of the mental because mental states are to characterize, and to describe causally. It is obvious that causal-relations are not inherent in the first-person stance. In contrary the mental is to understand from its own perspective.

It was discussed since the 1980s years that there is the leading problem of Fodor's theory. How do we solute the difficulty to bring together the internalistic computer theory, and an externalization of mental content? Michael Stich, for example, has argued that both is not to harmonize: a representational theory of mind whose generalizations of cognitive psychology refer to a representational content, and the same time a computational theory of mind does not refer to any content. ${ }^{12}$

The intuition of functionalism is that mental states (events) are states in a causal (functional) network in the mental history of a living organism. The theoretical model is the analogy with a computer program. The internal states are to specify exclusively as sequences by inputs, or outputs. The in- and outputs are to describe in non-mentalistic vocabulary. The most functionalists made the assumption that its account harmonizes with materialism.

Since the 1970s, Wilfrid Sellars's repudiation of the "myth of the given", stressing the distinction between explanation and justification, as well Willard van Orman Quine's critique on the distinction between analytic and synthetic have been dominating views. Sellars claim was that the distinction between explanation and justification undermined the idea that everything is given to the mind. Quine's view of keeping a distinction between the conceptual and the empirical, in spite of the critique of the analytic-synthetic distinction, was repudiated by Davidson in his critique of the "the third dogma of empiricism". This goes along with holism in epistemology, and the critique on mental representations. In the 1990s the situation was very much changed by Fodor's and Ernest Lepore's critique of holism. ${ }^{13}$

12 M. Stich, "Narrow Content meets Fat Syntax," pp. 239-54. In B. Loewer, G. Ray (eds.), Meaning in Mind. Fodor and his Critics. Cambridge Mass. 1991, see also, J. R. Searle critique on functionalism.

13 J. Fodor, E. Lepore, Holism, Oxford GB 1992. 


\section{Quine-Davidson Tradition}

1. Post-empiricism theory of meaning. One of the main subjects in the theory of meaning of the last forty years has been that meaning and belief are interconnected. This is called the circle between belief and meaning an interpreter has to break in so-called. Every theory of meaning has to give an answer to this problem. This takes effect in the philosophy of mind, language, and our understanding of the mental.

Quine's turn is well-known as a post-empiricism theory of meaning, which is continued in Davidson's interpretive theory as a unified theory of thought, meaning, action, and evaluation. ${ }^{14}$ He claims to give human agency, the mental, and language their place in nature. Quine and Davidson have concluded from the interconnection of belief and meaning that there is a methodologically significant non-distinguishability between both. For a non-analytical proposal of the theory of meaning, understanding meaning is always a translation in an ontological (linguistic) framework. Such a framework is not to be used as an objective pairing of expressions to entities, that is, it is not something we have definitely. On the contrary, the framework plays a role as a theory about the world. This theory consists of a set of sentences (truths) of particular entities (ontological commitments). Therefore, understanding meaning is a translation of sentences in a theoretical framework within, which we talk already about particular entities. Only in the frame of a translation in a theory can we understand the content of linguistic behaviour as speech about some object in the world. Holism in semantics and epistemology is rejected by Semanic Minimalism. (Fodor, Lepore, Emma Borg, and others ${ }^{15}$ )

2. First person authority. Quine's and Davidson's assumption of obvious conditions of understanding as natural conditions, and the semantic (truth-) conditions of the individual behaviour of speakers are not convincing arguments ultimately. Davidson claims to explain firstperson authority as a complement, which the interpreter assumes from the third-person stance does not work ultimately because the no-inferential knowledge of the first-person authority is changed from an epistemic to a causal role in the framework of the individuation of the con-

14 See, on Quine, Preyer, "From Radical Translation to Radical InterpretationFrom Quine to Davidson and beyond, Academia under Gerhard Preyer, unit Quine, Davidson. On Davidson's concept of evaluation Preyer, "Evaluative Attitudes," pp. 325-42. In J. Malpas (ed.), Dialogues with Davidson. Acting, Interpreting, Understanding. Cambridge Mass 2011.

15 See, on Semantic Minimalism Preyer, G. Peter (ed.), Context-Sensitivity and Semantic Minimalism. New Essays on Semantics and Pragmatics, Oxford GB 2007, Preyer, "Preface to the Second Edition: On Contemporary Philosophy Preface." Interpretation, Language, and the Social. Philosophical Article, Frankfurt a. M. $2012^{2}$. 
tent of thought by distal stimulus. ${ }^{16}$ The assumption that the speaker knows what he says, and is thereby to interpret is not an explanation of the first-person authority, and the asymmetry in the speaker's knowledge. Therefore there is no quasi-indication in the procedure of radical interpretation, and it is not given an adequate analysis of the epistemic position of the speaker (thinker) with respect to its self-reference.

The question whether radical interpretation is possible cannot be answered by the introduced principles of rationality (charity) as a constraint of interpretation. ${ }^{17}$ Therefore we must ask again what are the requirements (restrictions) of interpretation in the framework of the theory of meaning? This leads to a re-evaluation of the museum myth (Quine), the myth of the subjective (Davidson), the role of propositions in the theory of meaning and truth, and also of the third dogma of empiricism. We must also take into play in the procedure of interpretation, the epistemic restriction, the phenomenal consciousness, and the first-person authority of both the speaker and the interpreter. These restrictions cannot be eliminated by the theories of interpretation. The problem of Quine's and Davidson's proposal is that the conditions of understanding are obvious as natural conditions, and as truth-conditions of the linguistic behaviour of an individual speaker under study.

Davidson's view is, for example, that the assumption of inner entities (abstract entities; Frege-Thought) is determined by relations to such entities. From Davidson's point of view British empiricists (Locke, Berkeley, Hume) have the same problem like Cartesians. They have not shown how inner entities stand in a relation to outer entities, which they cause. Therefore, the individuation condition is specified by external relations. Externalism argues that the content of thought is to individuate by the external environment outside the thinker (speaker, agent) in principle: there are no object of thoughts I myself have. This is a consequence of Quine's museum myth. In the meantime there are reasonable doubts that this turn is the last word in epistemology. The third-person stance is the dogma of all naturalized epistemologists in the Quine-Davidsontradition. The question is: why are not mental propositions, and is the third-person stance of interpretation a global attitude in epistemology!? The leads to a rebuilding of the theory of interpretation.

3. Antirepresntationalism. Davidson mades an anti-representationalistic turn in epistemology and the theory of mind by his critique on the fact-representation relationship and the scheme-content dualism

16 On critique Lepore/K. Ludwig: Donald Davidson. Meaning, Truth, Language, and Reality, Oxford 2005, pp. 343-72.

17 Preyer, Evaluate Attitudes. In: Malpas (ed.), Dialogues with Davidson, on the "principle of tolerance" as a alternative principle, pp. 335-336. 
as a conceptual relativism (the third dogma of empiricism). ${ }^{18}$ The scheme is a conceptual representational system, and the content is the neutral and uninterpreted experience, which is given from outside of schemes. The last is also a critique on Quine's epistemology of stimulus meaning as a neutral content. Thoughts, utterances, inscription have not a content, and thereby a property. There are no inner objects mediating our access to the world, or a prior reference relation (no building block theory).

The epistemic anti-mentalism goes along with a rejection of the ontology of facts, state of affairs, and contrafactual assumptions. Sentences do not stand for facts as non-linguistic entities, for example, objects, properties, and relations. This is a "structural-correspondent" theory of truth. The new turn in the critique on mental representations and the scheme-content dualism is done with a logical argument. Both sides the epistemological and the ontological are dependent because if there are no facts then there is nothing to representate. It is called following Jon Barwise and John Perry "slingshot argument" as a collapsing argument. ${ }^{19}$ The question is that logical equivalent sentences stand for the same fact. The most philosophers would agree that the slingshot argument is not successful, that is, Davidson has not demonstrated that two singular terms are logical equivalent. ${ }^{20}$ The assumption is made that logical equivalent sentences stands for the same fact. The question is: how plausible is the principle that logical equivalent sentences have the same referent. ${ }^{213}$ If we accept the Frege-argument "the reference of a sentence is the truth value" then we may hold comprehensible this principle. But what is the constraint of this assumption. This leads back to Frege implausible assumption that an assertive sentence is a complex

18 On Davidson's critique of the third dogma of empiricism N. Rescher, "Conceptual Schemes," 323-45. In P. A. French et al. (eds.), Midwest Studies on Philosophy V. Studies in Epistemology, Minneapolis 1980. The problem is that the content is given us by the expressibility of language therefore there is a structure call this frame/scheme, what ever, which gives us the differentiation of content.

19 The argument is ascribed to Frege. On a resystematization of the slinghot argument with reference to their different versions of A. Church und K. Gödel, R. Carnap, Quine, and also R. Rorty's misinterpretation of Davidson's anti-representationalism, see, S. Neale, Facing Facts, Oxford 2001, on Neale ProtoSociology Vol. 23, 2006: Facts, Slingshots and Anti-Representationalism. On Stephen Neale's, Facing Facts'. Gerhard Preyer and Georg Peter (eds.). On critique on pragmatism Davidson, The Centrality of Truth (If Any), pp. 105-15 In. J. Peregrine ed., Dordrecht 1999. Contrary to Tarski propositions are required in the theory of truth, see, Preyer, "Von der Radikalen Interpretation zur Radikalen Interpretation - Von Quine zu Davidson und darüber hinaus". Academia under Gerhard Preyer, unit Quine, Davidson.

20 See, Lepore/Ludwig: Donald Davidson. Meaning, Truth, Languag, and Reality, pp. 49-55.

21 R. Schantz, Wahrheit, Referenz und Realismus. Eine Studie zur Sprachphilosophie und Metaphysik, Berlin 1996, 155, 160, on Frege pp. 156-163. He argues that Davidson's slingshot argument is blocked by Russel's theory of description. 
singular term, and the truth value is the referent: the True and the False. We should ask: why we need the word "fact"? One answer could be that we need a word to state that the conditions of illocutionary act are fulfilled. But this is not an turn to an ontology of facts (Russell, Wittgenstein in the Tractatus).

3. Charity and underdetermination of the content of thought. Basis rationality (charity) itself cannot give us the constraint of interpretation because it may be there are different mental states, classificatory concepts of our mental language, and also different antecedence condition that are not to research. We do not know, for example, the causes of people's taste in the Middle Ages. This leads us back to the relationship between the mental, language, and communication. The mental is unterdeterminated by behaviour. This underdetermination is reasoned (conceptually) from the subjective point of view epistemically. The mental is not determinated by behaviour ultimately. There are many different relations of coming real of the mental. Therefore the spring of the underdetermination is not to explain by an externalistic version of epistemology, that is, by the underdetermination of the content of thought about meaning (thought content) by behavioural evidence reasoned from the thirdperson point of view of an interpreter (translator). From the third-person point of view the ascription of thoughts, and the existence of other minds can only be establish by contingent correlations between mental states and behaviour. But first-person authority without self-reference as the subject's point of view is not the methodological stance of interpretation..$^{22}$

Quine's stimulus meaning with claims to filter out the so-called netmeaning, and the obvious common (distal) causes (Davidson: the language-grounded-externalism) cannot be the guarantee of redescription, and individuation of the content of thought, and fitting thereby the relationship between the mental, language, and the world. The mental language (-indexicals) are the constitutive feature of consciousness, and the public language. It is not argued that language is an exotic vocabulary, which is to explain by behaviour, physics, or biology. The supervenience of the description of one sort to description on the other sort does not have the conceptual resources to connect the mental, language, and communication. At this point we recognize the problem of understanding meaning, language, the social, and other culture.

22 This is emphasized from E. Lepore, K. Ludwig, Donald Davidson. Meaning, Truth, Language, and Reality, Oxford 2005, p. 368. 


\section{Self-Ascription of Mental States and the Privileged Access}

1. Individuation of content. Many philosophers agree that there are two problems about the individuation of content: firstly, the epistemic one that the thinker (speaker, agent) is conscious about his mental states, and secondly, the first person authority of the thinker (speaker, agent). ${ }^{23}$ The first is caused by the acquisition of knowledge from outside. This cannot be assumed a priori. Therefore situations of the acquisition of knowledge are to take into play. Secondly, first person authority means that the thinker (speaker, agent) has his authority knowing the content of his intentional states, but the content is to individuate externally. At the same time he knows the content directly without evidence. His knowledge is authoritative in contrast to knowledge by behavioural evidence. This is emphasized by Davidson. But the problem of non-evidential knowledge is not one of externalism itself. It is the problem of the role of the thinker's (speaker's, agent's) direct knowledge of mental states, and also of their content. ${ }^{24}$

There is a broad consent among philosophers that the mental (consciousness) is not to characterize by intentionality in general nor externally by the individuation of its content. Externalism may be reasoned partially, that is, there is a world outside from us we assume in common sense. But such view is in conflict with the epistemic authority with respect to the content of our own conscious mental states epistemically. The thinker (speaker, agent) has a privileged access to his mental states as an inner realm of thoughts, concepts, ideas, and subjective experience (phenomenal consciousness). The first person attitude on intentional states is immediate, and there is a direct knowledge of their content without inferences.

2. Symmetric and asymmetric accounts of self-ascription. In contemporary philosophy there are two accounts to characterize the self-ascription of mental states, and attitudes: a symmetric, for example Daniel Dennett, and also Peter F. Strawson because their view is that we ascribe us mental predicates in the same attitude like body predicates, and an asymmetric account, for example, Davidson, and others). For the first is valid that the thinker (speaker, agent) ascribes itself mental states in the same way he ascribes mental states to others. Therefore the established criteria of the ascription of attitudes are the same in the first-, second-, and third-person attitude. Dennett's intellectual background, for example, comes from Quine naturalized epistemology. We may call his account

23 See also, Externalism in the Philosophy of Mind, pp. 101-3.

24 Edwards, Externalism in the Philosophy of Mind, pp. 101-3. 
an internalist interpretationism: "a sort of inveterate auto-psychologist, effortless inventing intentional interpretation of our own actions in an inseparable mix of confabulation, retrospective self justification, and ... good theorizing." ${ }^{25}$ For the second, self-ascription of mental states, and to others are asymmetrical to understand in principle. The Davidsonview of the positive answer of self-ascription is that such ascription lacks the conditions of the third-person stance. The asymmetry is the basis relationship of radical interpretation, which claims to solute the task of intelligible redescription of linguistic behaviour, and the individuation of the content of thought. ${ }^{26}$ Davidson's turn in harmony with the epistemology of Quine is that interpretation is bound on the third-person attitude, and this stance of interpretation is to complete with the first-person authority from the speakers side under study. He calls all propositional attitudes thoughts. Propositional contents as entities of attitudes are a successor of Frege-Thought. The problem is consequently: how are to individuate the entities (content) of thoughts? Does exhaust thoughts the mental?

3. Explanation of privileged access. The general epistemological assumption is that the first-person ascription is grounded by a privileged access of the thinker (speaker, agent). Therefore there is an asymmetry between the first-person, and the third-person stance in principle. Thirdperson ascription is based on inferences from the agent observed behaviour, and its environment. In contrary first-person access as a direct epistemic access is to contrast with that situation. Davidson's view is, for example, that the epistemic stance of the first-person access is in the most cases trivial, and no epistemic foundation of knowledge.

We can ask again: what is the privileged stance of the subjective point of view, and the method of first-person ascription? Self-monitoring, different versions of introspection (inner awareness) $)^{27}$ and inner sense are not successful methods to explain a privileged access. In this point Dretske's, and others argument are intelligible that introspection involves "looking inward", and that does not work. ${ }^{28}$ Self-ascription

25 D. Dennett, The Intentional Stance. Cambridge 1987, p. 91. On Dennett, see, Miguens, Preyer eds, "Introduction: Are There Blindspots in Thinking About Consciousness and Subjectivity?" pp. 14, 27. In Consciousness and Subjectivity, Miguens, Una Teoria Fisicalista do Conteúdo e da Consciência-Dennett e os debates da filosofia da mente. Porto, Campo da Letras.

26 Content externalism goes back to H. Putnam, "The Meaning of Meaning." In Mind, Language, and Reality: Philosophical Papers (2 Vols.), Vol. 2 Cambridge 1975, T. Burge, "Individualism and the Mental (1979)," pp. 100-81. In Foundation of Mind. Oxford 2007.

27 For example, A. I. Goldman, Pathways to Knowledge Private and Public. Oxford 2002, pp. 73-136, see also, D. M. Rosenthal, Consciousness and Mind. Oxford 2005, pp. $205,105-31$.

28 F. Dretske, Naturalizing the Mind. Cambridge MA 1995. 
(knowledge) does not assume that there is a happening of a mental state (or event) we aware. All awareness is a thetic consciousness and directed to the extern world. Inner awareness would be a "awareness" from an extern and third-person point of view to us self. Call that the fallacy of the third-person stance of the mental. We can make sense of "introspection" if we re-interpret the expression thereby that self-reference is not independent on the thinker's (speaker's) way of access we have intuitively. ${ }^{29}$ Sydney Shoemaker calls the assumption of independence (the "independence condition"). He takes this condition in the "broad perceptual model", and he claims to reject it.

Nagel, for example, has argued that the subjective point of view of our consciousness is in harmony with our folk psychological intuitions, and, at the same time, this is in correspondence with scientific researches. For Patricia Smith, and Paul Churchland, in contraire, a scientific theory of consciousness leads to a correction of our folk psychological intuitions in the continuation of the scientific progress in future. Dennett has a middle position between both. He goes along with the researches of experimental cognitive psychology, and explains consciousness as a set of the interaction of brain processes. The interaction of the relevant processes, which are changed continuously leads to the representation of the mental by consciousness (Muliple Drafts Model). From Dreske's intentional realism point of view is our mind a semantic machine. Its output (behaviour) is driven by meaning. He does not go along with an instrumentalistic interpretation of the mental, and a reduction of the intentional to neurobiology. The intentional content must be explained by the causal history, and the network of the organism within its environment (synchronic externalism). As a consequence of Dreske's externalism it is to conclude that propositional attitudes cannot be explained in terms of neurophysiology.

4. Critique on self-reference as epistemological condition. Davidson's also other externalists like Gilbert Harman, Dretske, Michael Tye, and also Ernst Tugendhat, for example, critique on the epistemic self-referential versions of first-person authority is reasoned by the rejection of an introspective faculty (awareness of inner objects) with respect to the content of the phenomenal consciousness. ${ }^{30}$ The conclusion is to extensive because the mental content, and the consciousness about it is not to distinguish. They also agree that there is no quasi-indication from the third-person point of view. Davidson, and Tugendhat characterize the first-person authority by an immediate knowledge, but not by selfconsciousness (primary consciousness). For Davidson the third-person

29 Shoemaker, The First Person Perspective an Other Essays. New York 1996, p. 225.

30 Davidson, "Knowing One's Own Mind" (1987), p. 37. In Subjective, Intersubjective, Objective, Oxford 2001. 
point of view is global: he is yours, and mine, and not a philosophical proposal only. Therefore he writes consequently from this point of view: "Knowledge of the content of our own minds must, in most cases, be trivial." ${ }^{31}$ If we have this view then we are blind about the role of selfconsciousness. The analysis the first-person authority, and the third-person point of view also their role in interpretation (translation) in the versions of naturalized epistemologies are to correct in principle. This leads back to the analysis of self-consciousness. Self-consciousness, and selfknowledge are epistemologically relevant, and significant for the analysis of psychological concepts, speech, and communication.

5. Learning of attitudes and actions. The analysis of the resources of the explanation of communication, and action is not framed by a primitive desire-belief version explaining actions, and an externalistic epistemology because the teaching of attitudes, and actions exemplifies to us that a physical externalism of the individuation of the objects of thoughts does not explain the resources of ascription of mental states because learning has preconditions. In this situation we find these resources of learning, and the self-ascription of mental states as well as making the distinction between our self, and others. It is a part of these resources that we learn to ascribe mental states to myself, which are no fictions. Have we learnt how to make this distinction between our self, and others, if we have gained an understanding about what are mental states and communication as intentional doings? 32 The answer is "yes" and "no" because "yes", we understand self- and ascription to others of mental states by making and handle this distinction, and "no" because we understand mental state only if we are conscious about them; we have them, and they are not constituted by ascription.

\section{Changed Situation}

1. Internalists and externalists. Since the mid of the 1970s year we are confronted with difficulties of two accounts of the philosophy of mind the internalists, and the externalists. Internalists are, for example, Jerry Fodor, Colin McGinn, Brian Loar, and John R. Searle, although when he declines functionalism. For them mental content is independent on the extern environment. Mental content is narrow in principle. Externalism in the philosophy of mind is emerged since the 1970s years from

31 Davidson, “Three Varieties of Knowledge (1991),” p. 217, “Empirical Content (1982)," pp. 159-175. In Subjective, Intersubjective, Objective. Oxford 2001.

32 Preyer, "Evaluative Attitudes," pp. 330-334. In Malpas (ed.), Dialogues with Davidson. 
Putnam's Twin-earth externalism. ${ }^{33}$ From the externalist point of view in opposite the mental content is to individuate by the extern environment, for example, Putnam, John McDowell, Burge, Gareth Evans, and Davidson. They argue all content is wide, and non-relational. Disjunctivism (McDowell, M. G. F. Martin) of perceptual experience is a version of externalism of mental states, that is, perceptions, and hallucinations have disjunctive explanation. The question is whether visual experience we have if we see the surface is occurred is the same also in the case we were hallucinating? ${ }^{34}$ I agree with Katalin Falkas about that if we find what the two subjects share on Earth and on Twin Earth then we focus the question what are internal states, and how the boundary between the internal and the external is to draw. ${ }^{35}$

Looking back to the philosophical tradition we classify Descartes, Locke, Hume, Husserl, and also Frege, independent on their particular philosophies, as internalists. Frege's account is mixed because he has an internalistic and an externalistic part in his philosophy of language because the Thought (Gedanke) is not a mental representation (Frege's argument from communication). It is also to mention the critique on functionalism of Net Block, David Calmers, Jackson, Nagel, Searle, and also Putnam anti-functionalistic turn, which takes effect in the philosophy of mind.

2. Critique on physicalism and functionalism. The situation was changed by the arguments against physicalism and functionalism:

1. The Kripke argument of rigid designators,

2. the "what is like" argument $\left(\mathrm{Nagel}^{36}\right)$,

3. the knowledge argument (Jackson) ${ }^{37}$, and

33 H. Putnam, "The Meaning of 'Meaning'". In Mind, Language, and Reality.

34 On critique on disjunctivism M. Tye, "Representationalism and the Transparency of Experience." Nous 36 (2002), pp. 137-51.

35 K. Farkas, The Subject's Point of View, Oxford GB 2008, p. 75.

36 Nagel, “What is it like to be a Bat?”. In The Philosophical Review 83 1974, pp. 435-50.

37 In the meantime Jackson, "The Knowledge Argument, Diaphanousness, " pp. 52-64 has changed his view in the context of the debate on representationalism: "The nature of experience qua experience is exhausted by how things are being represented to be, not by the fact that they are being so represented," p. 62, "In sum, if strong representationalism is correct, advocates of the knowledge argument face a dilemma. If the similary between red experiences that they see physicalists as failing to include in their picture of reality lies in the content, it implies nothing about which properties are instantiated in our world; if the similarity lies in the state with the content, it is inconsistent with the knowledge argument's claim that something about the kind of experience. Mary has on leaving the room shows that physicalism is false," pp. 62-63. "This view is: Mary does not acquire a new knowledge of facts, but a knowledge of merely intentional objects. On critique T. Alter, "Does Representationalism undermine the Knowledge Argument?," pp. 65-76. In T. Alter, S. Walter 
4. the absent qualia (zombie) argument (David Chalmers, and others: the hard problem of consciousness, that is, if zombies are possible metaphysically then is consciousness no physical state. ${ }^{38}$

1. -4 . are the arguments with respect to the same problem: physicalism does not state sufficient conditions having mental state, but necessary conditions only. ${ }^{39}$ Therefore there is an "explanatory gab", that is, no physical theory can explain consciousness. ${ }^{40}$ For the explanatory gab it is to distinguish the gab between phenomenal properties, and the two types of properties 1 . between phenomenological properties and physical-neurophysiological properties, and also 2 . between phenomenological properties and functional-cognitive properties. Last was called the "hard problem of consciousness" (problem of cognitive closure).

Joseph Levine has given the metaphysical argument of Kripke's rigid designation an epistemic turn. The argument is concluded in the context that the assumption of zombies leads to a skepticism of the first-person authority, and the critique on the Higher Order Theory of the mental. Lewin makes a turn to a self-representational analysis of mental states, which takes in the self-presenting feature of phenomenal, and the intentional states of the mental. He argues that the gab between the physical and the mental is stretched because 1 . if the red experience is self presenting and no relation then the question is: how it is to grasp as such, and 2. is the red experience a relation then the question is: how is to understand the relation between the self presenting mental states, and, for example, the red. This is the question of the self-reference of mental states.

(eds.), Phenomenal Concepts and Phenomenal Knowledge. New Essays on Consciousness and Physicalism, Oxford 2007.

38 Many theorists of mind argue in the meantime that the assumption of zombies is not a serious possibility.

39 Necessary condition because we assume that the total function of our brain process is not dead, von Kutschera, Philosophie des Geistes, pp. 169-70.

40 The riddle of consciousness goes back to a lecture of E. du Bois-Reymond the founder of experimental physiology "Über die Grenzen des Naturerkennens" (1872). In Estelle du Bois Reymond ed., Reden von Emil du Bois-Reymond (2 Vols.), 1. Vol., Leizpig 1912, pp. 441-473, that is, consciousness is not to explain by material conditions. T. H. Huxley argued in a similar direction. The use of "quale" as an introspective experience of a monadic, and qualitative property (a phenomenal particular) goes back to C. I. Lewis. The awareness of coloured entities as such is the registration of qualia. ,Phenomenal' and ,qualitative' is used often synonymously. Materialists have to eliminate qualia ultimately. There is a problem in principle: introspection has not an access to any physical property. D. Armstrong, P. Churchland, and W. G. Lycan are the awareness of ordinary mental states a monitoring (scanning). The model is the ordinary awareness. For materalists are mental representations states of the nerve system. Brain states represents the extern world, and the world in us. For C. D. Broad is introspection a superstition. 
5. The China room argument (Searle) as a critique on functionalism because semantic content is not implied in the syntactic program of a Turning algorism (program). ${ }^{41}$

The phenomenal experience (qualia, phenomenal consciousness, feelings, Thomas Nagel: what is it like/what-it-is-likeness, Alexis Meinong, and Husserl: wie uns zumute ist), and the intentional states (propositional attitudes) play a central role in explaining behaviour. A leading question is: what is the function of qualitative states, that is, we are familiar with our-self? Such states are not propositional. Is also to naturalize intentionality, and the semantic content of propositional attitudes?

3. Epiphenomenalism. In continuation till to the present there is discussed the problem of epiphenomenalism, that is, mental events are caused by physical events in the brain, and have themselves no causal power in contrary to folk psychology mental events are assumed as bring about causal effects in the physical world. Epiphenomenalism is motivate by a physicalism picture of the world, and make a compromise with our every day life intuition of the existence of non-physical mental properties. The basic assumption are the causal closure of the physical, a causal theory of knowledge, meaning, reference, and memory.

But this hybrid situation in the theory of mind shows that there are conscious experiences, which are not in harmony with the naturalized epistemology, and the materialistic physicalism as well. Searle, Alfred Cyril Ewing, and others have argued that epiphenomenalism is wrong, and mental states have causal power by themselves. ${ }^{42}$ The question in the philosophy of mind is connected with the leading topics in the analytical theory of action since the beginning of the 1960 s years. ${ }^{43}$ But there is a confusion about the subject in question. If we argue that men-

41 On the first Kripke-debate in the second part of the 1970s years, see, for example, S. P. Schwartz (ed.), Naming, Necessity, and Natural Kinds, Ithica 1977, on Kripke Preyer, Interpretation, Sprache und das Soziale, Philosophische Artikel. Frankfurt a. M. 2012², pp. 251-55, Frank, "Varieties of Subjectivity," pp. 176-177. In Miguens, Preyer eds., Consciousness and Subjectivity, J. Levine, "Qualia, Materialism, and the Explanatory Gab". In Pazific Philosophical Quarterly 64 (1983), 354-361, “Conscious Awareness and (Self-)Representation," pp. 173-197. In U. Kriegel, K. Williford (eds.), Self-Representation to Consciousness, Cambridge 2006, D. J. Chalmers, "Facing up to the Problem of Consciousness", Journal of Consciousness Studies 2 (1995), pp. 200-19, J. R. Searle, "Minds, Brains, and Programms," The Behavioral and Brain Sciences, 3 (1980), pp. 417-424, on the debate among German philosophers about the identity theory, and the phenomenal consciousness M. Pauen, A. Stephan Hrsg., Phänomenales Bewusstsein - Rückkehr zur Identitätstheorie?. Paderborn 2002.

42 A. C. Ewing, The Fundamental Problems of Philosophy, New York 1953.

43 G. Preyer, Intention and Practical Thought, Frankfurt a. M. 2011, see, “Geographical Overview Analytical Philosophy of Action", pp. 9-32. 
tal states have not causal power then it is not implied that they are fictions. Reasons and actions are no causes. Actions are always "first causes", that is, we do not cause actions, but we take effects by actions. The beginning of a deed is the deed itself. It is to make the distinction between agent and event causality. ${ }^{4}$

Partially we have good reasons to go along with the mentioned critique of physicalism because there is an explanatory gap between neurological explanations, and the intentional and phenomenal states, we do not describe in a thing-event language. Mental states cannot be reduced by definition analytically, or bridge laws between the physical and the mental. It does not make sense to read the mental idiom into the neurological description. Neurophysiological explanations are "explanation" in a model. This is not a critique on neurophysiologists. It is a limitation of the explanatory power of their theories. Therefore it is to recommendate an epistemic-critical attitude toward a scientific realism.

In the meantime it is obvious that mental predicates are not expressions, which have their meaning by theories only. They have a meaning in our common communication, and we know them without to know a theory, for example, about the causal roles of perceptions, and qualia. The functionalism makes also the assumption that human behaviour is determinated causally. Therefore there is no freedom. Also this assumption is not reasoned by functionalists.

\section{Conclusion}

From the exposed route of posing the initial situation of the philosophy of mind (mental) is to conclude: consciousness is autonomous epistemically if we recognize that its elementary feature is its basal self-reference and a perspective, which has not an echo in the physical. Looking back there are two opposite accounts internalism and externalism in epistemology, philosophy of mind, and language. The problem of internalism and externalism is emerged in the philosophy of the mental since the 1970s years: internalism (individualism) is the position that mental states are independent on the physical, and social environment. ${ }^{45} E x$ ternalism is a critique of Cartesianism (Cartesian intuition). Contrary to Cartesians the externalists have argued that some psychological states

44 Von Kutschera, Philosophie des Geistes, p. 45, on freedom of action, and free will, pp. 41-56. Preyer, Intention and Practical Thought, on actions, and body movements, pp. 43-46, what action theory is possible?, pp. 46-52, an intentional explanation, pp. $82-89$.

45 J. Fodor, Psychosemantic, Cambridge 1987. 
are individuation-dependent on certain aspects of the physical, and social environment. Mental states are to individuate externally. Externalism is confronted not only with the immediate consciousness of one's own mental states, but also with self-knowledge of my/her/himself as my/ her/himself, and internalism is confronted with the problem of the link among mental states, and their individuation (fitting problem, problem of disjunctivism).

The debate in contemporary philosophy of mind between internalism, externalism is focused about the relationship between mental, language, the social, and the world. We conclude from the debate between internalism and externalism: the mental content may be individuated by external conditions like public conditions of verifiability, or direction of fit. But the ontology of consciousness is subjective, that is, having a mode of existence, which is dependent from the subject's point of view. The turn is not an argument for a relativism in epistemology in general because this does not imply that we cannot state fulfilment conditions about mental state. The immediate mental states are self-fulfilled by themselves epistemically. It is to drop to characterize self-consciousness by representation, or second order acts. ${ }^{46}$

\section{Bibliography}

Alter, T., 2007, „Does Representationalism undermine the Knowledge Argument?," pp. 65-76. In T. Alter, S. Walter eds., Phenomenal Concepts and Phenomenal Knowledge. New Essays on Consciousness and Physicalism, Oxford.

Armstrong, D. 1968, A Materialist Theory of Mind, New York.

du Bois-Reymond, E., (1872) 1912, „Über die Grenzen des Naturerkennens“ In Estelle du Bois Reymond ed., Reden von Emil du Bois-Reymond (2 Vols.), 1. Vol., Leizpig, pp. 441-473.

Burge T., (1993) 2007, "Mind-Body Causation and Explanatory Practice," In Foundation of Mind. Oxford.

Burge, T., (1979) 2007, "Individualism and the Mental," pp. 100-81. In Foundation of Mind. Oxford.

Chalmers, D. J., 1995, "Facing up to the Problem of Consciousness," Journal of Consciousness Studies 2, pp. 200-19,

Davidson, D., (1970) 1980, "Mental Events," pp. 207-25. In Actions and Events, Oxford.

Davidson, (1987) 2001, “Knowing One's Own Mind," In Subjective, Intersubjective, Objective, Oxford.

46 Book Excerpt from G. Preyer, Back to Cartesian Intuition. Internalism, Externalism and the Mental. Manuscript 2015. 
Davidson, (1991), (1982), 2001, "Three Varieties of Knowledge,", “Empirical Content," pp. 159-175. In Subjective, Intersubjective, Objective. Oxford.

Dennett, D., 1987, The Intentional Stance. Cambridge.

Edwards, S., 1994, Externalism in the Philosophy of Mind, Avebury.

Ewing, A. C., 1953, The Fundamental Problems of Philosophy, New York.

Farkas, K., 2008, The Subject's Point of View, Oxford GB.

Fodor, J., Lepore, E., 1992, Holism. Oxford GB.

Fodor, J., 1987, Psychosemantic. Cambridge.

Frank, M., 2013, "Varieties of Subjectivity,", In Miguens S., Preyer, G., (eds.), Consciousness and Subjectivity, Berlin, De Gruyter.

Goodman, N., 1978, Ways of World Making, Indianapolis.

Kim, J., 1996, Philosophy of Mind, New York.

Kim, J., 1993, Supervenience and Mind. Selected Philosophical Papers, Cambridge.

Lepore, E., Ludwig, K., 2005. Donald Davidson Meaning, Truth, Language, and Reality. Oxford, Clarendon Press.

Levine, J., 1983, "Qualia, Materialism, and the Explanatory Gab", In Pazific Philosophical Quarterly 64, 354-361.

Levine, J., 2006, “Conscious Awareness and (Self-)Representation," pp. 173197. In U. Kriegel, K. Williford eds., Self-Representation to Consciousness, Cambridge.

von Kutschera F., 1993, Die falsche Objektivität, Berlin,

von Kutschera F., 1992, "Supervenience and Reduction," Erkenntnis 36.

von Kutschera F., 2009, Philosophie des Geistes, Paderborn.

Lewis, D. 1972, "Psychophysical and Theoretical Identification," Australasian Journal of Philosophy 50, pp. 249-58,

Macintyre, A. C., 1958, The Unconscious. A Conceptual Analysis, London, Routledge.

Miguens S., Preyer, G., (eds.). 2013. Consciousness and Subjectivity, Berlin, De Gruyter.

Nagel, T., 1974, "What is it like to be a Bat?", In The Philosophical Review 83, pp. $435-50$.

Neale, S., 2001, Facing Facts, Oxford.

Pauen, M., Stephan A. 2002, (eds.), Phänomenales Bewusstsein - Rückkehr zur Identitätstheorie?, Paderborn.

Peregrine, J., (ed.), 1999, The Centrality of Truth (If Any), Dordrecht.

Preyer, G. Miguens, S., Morando Bravo C. (eds.) 2015, Pre-Reflectivity. Sartre and Contemporary Philosophy, Abingdon: Routledge.

Preyer, G., 2012², Interpretation, Sprache und das Soziale, Philosophische Artikel. Frankfurt a. M., pp. 251-55.

Preyer, G., 2015, “From Radical Translation to Radical InterpretationFrom Quine to Davidson and beyond," Academia under Gerhard Preyer, unit Quine, Davidson.

Preyer, G., 2011, “Evaluative Attitudes,” pp. 325-42. In J. Malpas eds., Dialogues with Davidson. Acting, Interpreting, Understanding. Cambridge Mass. 
Preyer, G., 2011, Intention and Practical Thought, Humanities-Online, Frankfurt a. M.

Preyer, G., Peter, G., 2006, ProtoSociology Vol. 23: Facts, Slingshots and AntiRepresentationalism. On Stephen Neale's ,Facing Facts'.

Putnam, H., 1975, “The Nature of Mental States," In Philosophical Papers II, Cambridge.

Putnam, H., 1975, “The Meaning of Meaning," pp. 215-71. In Mind, Language, and Reality: Philosophical Papers (2 Vols.), Vol. 2 Cambridge.

Rescher, N., 1980, “Conceptual Schemes," pp. 323-45. In P. A. French et al. eds., Midwest Studies on Philosophy V. Studies in Epistemology, Minneapolis.

Rogler E., Preyer G., 2001, Materialismus, anomaler Monismus und mentale Kausalität. Zur gegenwärtigen Philosophy des Mentalen bei Donald Davidson und David Lewis, Frankfurt a. M., pp. 25-62,

Rogler E., Preyer G, 2001, "Anomalous Monism and Mental Causality. On the Debate of Donald Davidson's Philosophy of the Mental." Free to download https://ssl.humanities-online.de see, OpenAcess

Savellos E. E. (ed.) 1995, Supervenience: New Essays, Cambridge.

Schantz ,R., 1996, Wahrheit, Referenz und Realismus. Eine Studie zur Sprachphilosophie und Metaphysik, Berlin.

Schwartz, S. P., 1977, (ed.), Naming, Necessity, and Natural Kinds, Ithica.

Searle, J. R., 1980, “Minds, Brains, and Programms," The Behavioral and Brain Sciences, 3, pp. 417-424.

Sellars, W. 1963, Science, Perception, and Reality, London.

Shoemaker, S., 1984, "Functionalism and Qualia," In Identity, Cause and Mind, Cambridge.

Stalnaker, R. C. 2008, Our Knowledge of the Internal World, Oxford.

Stich, M., 1991, “Narrow Content meets Fat Syntax," pp. 239-54. In B. Loewer, G. Ray eds. Meaning in Mind. Fodor and his Critics. Cambridge Mass.

Tye, M., 2002, "Representationalism and the Transparency of Experience," Nous 36, pp. 137-51.

von Wright G. H., 1994, “Die menschliche Freiheit,” pp. 136-37. In Normen, Werte und Handlungen, Frankfurt a. M.

\section{Summary}

The aim of the paper is to present the main conceptions in the cotemporary philosophy of mind. The debate is narrated in two ways: The first approach concerns the ontology of mind, with the questions such as: What is the nature of mind?; What is the relation between mind and body?; Is the mind reducible to its physical basis? The second approach has an epistemological character where especially the problem of self-knowledge in the frame of the discussion between externalism and internalism is pointed out. The last part of the article gives an evaluation of the actual situation in the philosophy of mind which on the one 
hand tries to evolve in the direction of cognitive science but on the other hand stays in the frame of the traditional philosophy. The reason of it is the nature of the questions, which cannot be answered only by means of scientific disciplines. It means that in contrast to the cognitive science the philosophical account of the mind-body problem is the preferred one.

\section{Keywords}

Philosophy of mind, mind-body problem, externalism, internalism, cognitive sciences 